\title{
PENGARUH KEPEMIMPINAN GURU DAN KETERAMPILAN MENAJEMEN KELAS TERHADAP PERILAKU BELAJAR SISWA DI SDI ISLAM 01 YMI WONOPRINGGO
}

\author{
${ }^{1}$ Nur Ismiati, ${ }^{2}$ Zaenal Mustakim, ${ }^{3}$ Saefudin Zuhri, ${ }^{4}$ Umi Mahmudah \\ ${ }^{1}$ Pascasarjana IAIN Pekalongan \\ ${ }^{2,3,4}$ IAIN Pekalongan \\ Nurismiati7@gmail.com
}

\begin{abstract}
ABSTRAK
Salah satu perwujudan dari kepemimpinan guru yaitu dengan adanya manajemen kelas. Untuk itu apabila kepemimpinan guru dikaitkan dengan keterampilan guru dalam melakukan manajemen kelas maka terdapat keterkaitan yang sangat erat. Semakin berkualitasnya manajemen kelas, semakin baik pula kepemimpinan guru tersebut. Kemudian lebih lanjut dalam sebuah proses pembelajaran di kelas, diharapkan mampu menciptakan perilaku positif ketika siswa sedang mengikuti aktivitas belajar. Namun pada kenyataannya membentuk perilaku positif siswa saat sedang mengikuti pembelajaran tidaklah mudah, perlu adanya kepemimpinan yang berkualitas dan di dampingi oleh keterampilan manajemen kelas yang baik. Tujuan dari penelitian ini adalah untuk mengetahui pengaruh kepemimpinan guru dan keterampilan manajemen kelas terhadap perilaku belajar siswa. Adapun jenis penelitian yang digunakan adalah penelitian lapangan (field research) dengan pendekatan kuantitatif. Berdasarkan dari hasil uji persamaan regresi linier berganda yang dilakukan oleh peneliti dapat disimpulkan bahwa kepemimpinan guru dan ketrampilan manajemen kelas mempunyai pengaruh terdapat perilaku siswa. hal ini dibuktikan dengan perolehan nilai $\mathrm{F}$ hitung 32,075 $>\mathrm{F}$ tabel 4,02 .
\end{abstract}

Kata Kunci: Kepemimpinan Guru, Manajemen Kelas, Perilaku Belajar

\section{PENDAHULUAN}

Guru merupakan seorang pengajar sekaligus pendidik yang tugasnya menjalankan proses pembelajaran didalam kelas, baik kelas tersebut berbasis indor, outdor, offline, maupun online. untuk itu berkualitas atau tidaknya kelas tergantung bagaimana cara kepemimpinan yang diterapkan guru dalam kelas. Kepemimpinan guru disini dapat diartikan bagaimana cara guru dalam mengatur dan membuat kebijakan di dalam kelas. sejalan dengan pendapat dari Amiruddin Siahaan yang mengatakan bahwa salah satu hal utama yang dapat 
dilakukan dalam upaya memperbaiki sekolah/ peningkatan mutu sekolah, yaitu dengan cara berinvestasi pada kepemimpinan guru dan membangun kapasitas guru untuk perbaikan melalui pemberian tanggung jawab kepemimpinan kepada para guru didalam kelas. ${ }^{1}$ Menurut Edeg Suryana mengatakan bahwa sebagai seorang pemimpin pembelajaran di dalam kelas, pengaruh dan peran guru begitu sangat besar dalam meningkatkan hasil belajar siswa. Hal tersebut dikarenakan berkembangnya semangat belajar siswa atau minat terhadap materi pembelajaran, dan suasana belajar banyak ditentukan oleh kualitas kepemimpinan guru. ${ }^{2}$

Adapun salah satu perwujudan dari kepemimpinan guru yaitu dengan adanya manajemen kelas. Manajemen kelas merupakan suatu upaya guru dalam mengatur kelas dengan tujuan agar sebuah pembelajaran yang dilakukan dapat mencapai tujuan yang telah ditetapkan. Sejalan dengan pendapat dari Erwin Widasworo yang mengatakan bahwa manajemen kelas berkaitan dengan upaya yang dilakukan oleh guru, meliputi perencanaan, pengaturan, dan pengoptimalan berbagai sumber, bahan, serta sarana pembelajaran yang efektif dan berkualitas bagi peserta didik.3 Untuk itu apabila kepemimpinan guru dikaitkan dengan keterampilan guru dalam melakukan manajemen kelas maka terdapat keterkaitan yang sangat erat. Semakin berkualitasnya manajemen kelas, semakin baik pula kepemimpinan guru tersebut.

Kemudian lebih lanjut dalam sebuah proses pembelajaran di kelas, diharapkan mampu menciptakan perilaku positif ketika siswa sedang mengikuti aktivitas belajar. Namun pada kenyataannya membentuk perilaku positif siswa saat sedang mengikuti pembelajaran tidaklah mudah, perlu adanya kepemimpinan yang berkualitas dan di dampingi oleh keterampilan manajemen kelas yang baik. hal ini dikarenakan siswa memiliki kecenderungan minat belajar yang berbeda-beda. Apalagi untuk usia SD/MI dimana siswa memasuki tahap perkembangan Oprasional konkrit. Pada tahap ini siswa biasanya cenderung belum bisa belajar dengan berfikir analisa tingkat tinggi, untuk itu masih diperlukannya benda-benda konkrit atau media pembelajaran yang dapat membantu menyampaikan materi pembelajaran. Dengan adanya kepemimpinan guru di kelas dan juga keterampilan guru melakukan manajemen kelas diharapkan mampu menciptakan suasana belajar yang kondusif dan juga sesuai dengan kondisi perkembangan siswa, sehingga mampu memberikan dampak positif pada perilaku belajar siswa. Peter salim mengatakan bahwa perilaku belajar adalah cara atau

\footnotetext{
${ }^{1}$ Amiruddin Siahaan, Kepemimpinan Pendidikan, cet. ke- 1 (Medan: CV. Widya Puspita, 2018), hlm. 181

${ }^{2}$ Edeg Suryana, Administrasi Pendidikan dalam Pembelajaran, cet. ke- 1 (Yogyakarta: Deepublish, 2019), hlm. 55

${ }^{3}$ Erwin Widasworo, Cerdas Pengelolaan Kelas, cet. ke- 1 (Yogyakarta: DIVA Press, 2018), hlm. 13
} 
tindakan yang berisi sikap atas pelaksanaan teknik-teknik belajar yang dilaksanakan individu atau siapapun dalam eaktu dan situasi belajar tertentu.4

Di SD Islam 01 YMI sendiri kualitas kepemimpinan dan manjemen kelas merupakan hal yang dutamakan bagi setiap guru kelas, untuk itu rekrutmen guru dari awal seleksi masuk sudah diberikan tes mengenai kepemimpinan guru dan keterampilan dalam manajemen kelas. diharapkan nantinya setiap guru yang ada di SD Islam 01 YMI Wonopringgo mempunyai kecakapan dalam hal memimpin kelas dan terampil dalam melakukan manajerial kelas. berdasarkan hasil observasi awal dengan kepala sekolah SD Islam 01 YMI Wonopringgo mengatakan bahwa kemampuan memimpin kelas dan manajemen kelas merupakan hal penting bagi setiap guru kelas untuk itu ada beberapa upaya yang dilakukan guna meningkatkan kepemimpinan guru dan manajerial kelas, salah satunnya yaitu dengan melakukan monitoring pembelajaran. Dengan adanya monitoring diharapkan apabila ada kekurangan dalam hal kepemimpinan yang dilakukan guru dan juga sistem manajemen kelasnya dapat dicarikan solusi bersama, biasanya hal ini dilakukan dalam rapat evaluasi kinerja guru SD Islam 01 YMI Wonopringgo.

Berdasarkan latar belakang diatas maka peneliti tertarik untuk membuktikan apakah kepemimpinan guru di kelas dan juga keterampilan guru dalam melakukan manajemen dapat benar-benar memberi pengaruh pada perilaku belajar siswa. Oleh karena itu, tujuan utama penelitian ini adalah untuk mengetahui pengaruh kepemimpinan guru dan keterampilan manajemen kelas terhadap perilaku belajar siswa.

\section{METODE PENELITIAN}

Jenis penelitian yang digunakan dalam penelitian ini adalah penelitian lapangan (field research), yaitu penelitian dilakukan secara langsung kepada responden. ${ }^{5}$ Sedangkan pendekatan yang digunakan yaitu pendekatan kuantitatif, dinamakan pendekatan kuantitatif karena hasil dari penelitian berupa angka-angka, analisis data yang diperoleh dilakukan untuk mereduksi dan mengorganisasikan data, menemukan signifikansi hubungan, dan mencari perbedaan antar kelompok. ${ }^{6}$

\footnotetext{
${ }^{4}$ Peter salim, kamus besar bahasa indonesia kontemporer (Jakarta: Modern English Press, 1991), hlm. 1126

${ }^{5}$ M. Iqbal Hasan. Pokok-Pokok Materi Metode Penelitian dan Aplikasinya. (Jakarta: Ghalia Indonesia, 2002) hlm. 11.

${ }^{6}$ Slamet untung, metode penelitian teori dan praktik riset pendidikan dan sosial, cet. ke- 1 (Yogyakarta: Litera, 2019), hlm. 193
} 
Untuk lokasi penelitian dilakukan di SD Islam 01 YMI Wonopringgo, dimana dalam tahapan pelaksanaannya dilakukan dengan menyebar angket terhadap responden dan melakukan dokumetasi yang bertujuan untuk mengetahui pengaruh kepemimpinan guru dan keterampilan menajamen kelas terhadap perilaku siswa. Adapun Populasi penelitian ini adalah siswa kelas 4,5, dan 6 SD Islam YMI Wonopringgo yang berjumlah 55 anak. ke udian dalam menentukan sampel, peneliti mengacu pendapat Suharsimin Arikunto yang menjelaskan bahwa: "Apabila objeknya kurang dari 100, maka lebih baik diambil semua objeknya. Akan tetapi, jika objeknya lebih besar dari 100, maka diambil antara 10-15\% atau $20-25 \%$ atau lebih".7

Berdasarkan pendapat diatas, maka penelitian mengambil keseluruhan populasi untuk dijadikan sample yaitu 55 anak sebagai samplenya.

Lebih lanjut Variabel penelitian adalah ciri-ciri atau karakteristik suatu objek penelitan yang mempunyai taraf yang berbeda-beda pada setiap ciri-ciri tersebut. Variabel ini ditetapkan oleh peneliti. ${ }^{8}$ Adapun variabel yang ada dalam penelitian ini meliputi:

1. Variabel bebas/ Variabel X (Independent Variabel)

Dalam penelitian ini mempunyai 2 variabel bebas yaitu kepemimpinan guru (X1) dan keterampilan manajemen kelas (X2). Dengan indikator sebagai berikut:

Indikator kepemimpinan guru (X1), Menurut kartini kartono, ada tujuah yaitu sebagai berikut: ${ }^{9}$

a. Keterampilan berkomunikasi

b. Keterampilan mengajar

c. Keterampilan relasi insani

d. Objektivitas

e. Ketegasan dalam mengambil keputusan

f. Penguasaan teknis

g. Kecakapan manajerial

Indikator keterampilan manajemen kelas (X2), menurut Novan Ardy Wijayani meliputi: ${ }^{10}$

a. Menciptakaniklim belajar yang tepat

b. Mengatur ruang belajar

\footnotetext{
hlm. 145

${ }^{7}$ Suharsimi Arikunto, Prosedur Penelitian Suatu Pendekatan Praktis, (Jakarta: Rineka Cipta, 2006),

${ }^{8}$ Salafudin dan Nalim, Statistik Deskripstif, (Pekalongan: STAIN Pekalongan Press, 2012), hlm. 34.

${ }^{9}$ Kartono kartini, pemimpin dan kepemimpinan, (Jakarta: PT Grafindo, 1992), hlm. 37

${ }^{10}$ Novan Ardy Wiyani, manajemen kelas: teori dan aplikasi untuk menciptakan kelas yang kondusif, (Yogyakarta: Ar-Ruzz, 2013), hlm. 65-66
} 
c. Mengelola interaksi kegiatan belajar mengajar

2. Variabel terikat/ Variabel Y (dependent Variabel)

Yang termasuk variabel dependen pada penelitian ini adalah perilaku belajar siswa, dengan indikator sebagai berikut: ${ }^{11}$

a. Perubahan intensional

b. Perubahan positif dan aktif

c. Perubahan efektif dan fungsional

\section{HASIL DAN PEMBAHASAN}

Sebelum instrumen diujikan pada siswa kelas IV sampai dengan kelas VI SD Islam 01 YMI, maka untuk instrumen penelitian perlu dilakukan uji coba instrumen terlebih dahulu. Uji coba instrumen dibutuhkan dengan tujuan guna mengetahui apakah setiap butir soal sesuai kriteria kualitas soal yang baik atau belum. Adapun untuk Soal uji coba instrumen berjumlah 60 soal pilihan ganda, yaitu 20 soal tentang kepemimpinan guru, 20 soal tentang kreatifitas manajemen kelas, dan 20 soal tentang perilaku belajar. Setelah mendapat hasil uji coba instrument, maka tahap selanjutnya adalah menganalisis butir soal hasil uji coba instrumen. Analisis tersebut yaitu:

1. Uji validitas

Dalam pengujian validitas penelitian ini, penulis memakai rumus kolerasi product moment yang mana dalam pengujian validitas dimulai dengan mencari $r_{\text {hitung }}$ terlebih dahulu. Setelah $r_{\text {hitung }}$ ditentukan, tahap selanjutnya membandingkan $r_{\text {hitung }}$ dengan $r_{\text {tabel }}$ product moment dengan taraf signifikansi 0,05. Jika $r_{\text {hitung }} \geq r_{\text {tabel }}$, instrumen soal dapat dikategorikan valid. Sebaliknya jika $r_{\text {hitung }} \leq r_{\text {tabel }}$, maka instrumen soal dapat dikategorikan tidak valid. ${ }^{12} \mathrm{r}_{\text {tabel }}$ untuk jumlah $(\mathrm{N})$ responden 55 , dimana $\mathrm{df}=\mathrm{n}-2=53$ adalah 0,2658, Dalam pengitungan ini, penulis menggunakan bantuan SPPS 16.0.

Adapun hasil validitas instrumen soal angket untuk variabel X1 tentang kepemimpinan guru digambarkan melalui tabel 1 dibawah:

${ }^{11}$ Muhibbin Syah, psikologi pendidikan dengan pendekatan baru, (Bandung: Remaja Rosdakarya, 2010), hlm. 116

${ }^{12}$ Umi Mahmudah, Metode Statistika: Step by Step, (Pekalongan: Penerbit NEM, 2020) 
Tabel 1. Rangkuman Hasil Uji Validitas Angket tentang Kepemimpinan Guru

\begin{tabular}{|c|c|c|c|c|}
\hline Variabel & Butir Soal & $\mathbf{r}_{\text {hitung }}$ & $\mathbf{r}_{\text {tabel }}$ & Keterangan \\
\hline Kepemimpinan & 1 & 0,368 & 0,2658 & Valid \\
\cline { 2 - 5 } Guru (X1) & 2 & 0,490 & 0,2658 & Valid \\
\cline { 2 - 5 } & 3 & 0,351 & 0,2658 & Valid \\
\cline { 2 - 5 } & 4 & 0,374 & 0,2658 & Valid \\
\cline { 2 - 5 } & 5 & 0,299 & 0,2658 & Valid \\
\cline { 2 - 5 } & 6 & 0,281 & 0,2658 & Valid \\
\cline { 2 - 5 } & 7 & 0,276 & 0,2658 & Valid \\
\cline { 2 - 5 } & 8 & 0,303 & 0,2658 & Valid \\
\cline { 2 - 5 } & 10 & 0,313 & 0,2658 & Valid \\
\cline { 2 - 5 } & 11 & 0,425 & 0,2658 & Valid \\
\cline { 2 - 5 } & 12 & 0,540 & 0,2658 & Valid \\
\cline { 2 - 5 } & 13 & 0,663 & 0,2658 & Valid \\
\cline { 2 - 5 } & 14 & 0,596 & 0,2658 & Valid \\
\cline { 2 - 5 } & 15 & 0,478 & 0,2658 & Valid \\
\cline { 2 - 5 } & 16 & 0,625 & 0,2658 & Valid \\
\cline { 2 - 5 } & 17 & 0,662 & 0,2658 & Valid \\
\cline { 2 - 5 } & 18 & 0,679 & 0,2658 & Valid \\
\cline { 2 - 5 } & 19 & 0,663 & 0,2658 & Valid \\
\cline { 2 - 5 } & 20 & 0,606 & 0,2658 & Valid \\
\hline
\end{tabular}

Berdasarkan data tersebut diketahui bahwa semua item soal yang berjumlah 20 soal tergolong valid. hal ini disebabkan hasil $r_{\text {hitung }}$ semuanya lebih besar dari pada $r_{\text {tabel. }}$ Sedangkan untuk Uji validitas instrumen X2 tentang keterampilan manajemen kelas ditunjukan oleh tabel 2 berikut:

Tabel 2. Rangkuman Hasil Uji Validitas Angket tentang Keterampilan Manajemen Kelas

\begin{tabular}{|c|c|c|c|c|}
\hline Variabel & Butir Soal & $\mathbf{r}_{\text {hitung }}$ & $\mathbf{r}_{\text {tabel }}$ & Keterangan \\
\hline $\begin{array}{c}\text { Keterampilan } \\
\text { manajemen kelas } \\
\text { (X2) }\end{array}$ & 1 & 0,341 & 0,2658 & Valid \\
\cline { 2 - 5 } & 2 & 0,248 & 0,2658 & Valid \\
\cline { 2 - 5 } & 3 & 0,293 & 0,2658 & Valid \\
\cline { 2 - 5 } & 4 & 0,370 & 0,2658 & Valid \\
\cline { 2 - 5 } & 5 & 0,297 & 0,2658 & Valid \\
\cline { 2 - 5 } & 6 & 0,335 & 0,2658 & Valid \\
\cline { 2 - 5 } & 7 & 0,294 & 0,2658 & Valid \\
\cline { 2 - 5 } & 8 & 0,336 & 0,2658 & Valid \\
\cline { 2 - 5 } & 9 & 0,272 & 0,2658 & Valid \\
\cline { 2 - 5 } & 10 & 0,265 & 0,2658 & Valid \\
\cline { 2 - 5 } & 11 & 0,358 & 0,2658 & Valid \\
\cline { 2 - 5 } & 12 & 0,306 & 0,2658 & Valid \\
\cline { 2 - 5 } & 13 & 0,292 & 0,2658 & Valid \\
\cline { 2 - 5 } & 14 & 0,314 & 0,2658 & Valid \\
\cline { 2 - 5 } & 15 & 0,646 & 0,2658 & Valid \\
\hline
\end{tabular}




\begin{tabular}{|l|l|l|l|l|}
\hline \multirow{3}{*}{} & 17 & 0,489 & 0,2658 & Valid \\
\cline { 2 - 5 } & 18 & 0,495 & 0,2658 & Valid \\
\cline { 2 - 5 } & 19 & 0,537 & 0,2658 & Valid \\
\cline { 2 - 5 } & 20 & 0,688 & 0,2658 & Valid \\
\hline
\end{tabular}

Berdasarkan data tersebut diketahui bahwa semua item soal yang berjumlah 20 soal tergolong valid. hal ini disebabkan hasil $r_{\text {hitung }}$ semuanya lebih besar dari pada $r_{\text {tabel. }}$.

Tabel 3. Rangkuman Hasil Uji Validitas Angket tentang Perilaku Belajar

\begin{tabular}{|c|c|c|c|c|}
\hline Variabel & Butir Soal & $\mathbf{r}_{\text {hitung }}$ & $\mathbf{r}_{\text {tabel }}$ & Keterangan \\
\hline Perilaku & 1 & 0,247 & 0,2658 & Valid \\
\cline { 2 - 5 } Belajar (Y) & 2 & 0,335 & 0,2658 & Valid \\
\cline { 2 - 5 } & 3 & 0,605 & 0,2658 & Valid \\
\cline { 2 - 5 } & 4 & 0,342 & 0,2658 & Valid \\
\cline { 2 - 5 } & 5 & 0,312 & 0,2658 & Valid \\
\cline { 2 - 5 } & 6 & 0,284 & 0,2658 & Valid \\
\cline { 2 - 5 } & 7 & 0,295 & 0,2658 & Valid \\
\cline { 2 - 5 } & 8 & 0,476 & 0,2658 & Valid \\
\cline { 2 - 5 } & 9 & 0,281 & 0,2658 & Valid \\
\cline { 2 - 5 } & 10 & 0,395 & 0,2658 & Valid \\
\cline { 2 - 5 } & 11 & 0,553 & 0,2658 & Valid \\
\cline { 2 - 5 } & 12 & 0,658 & 0,2658 & Valid \\
\cline { 2 - 5 } & 13 & 0,439 & 0,2658 & Valid \\
\cline { 2 - 5 } & 14 & 0,481 & 0,2658 & Valid \\
\cline { 2 - 5 } & 15 & 0,552 & 0,2658 & Valid \\
\cline { 2 - 5 } & 16 & 0,544 & 0,2658 & Valid \\
\cline { 2 - 5 } & 17 & 0,474 & 0,2658 & Valid \\
\cline { 2 - 5 } & 18 & 0,360 & 0,2658 & Valid \\
\cline { 2 - 5 } & 19 & 0,491 & 0,2658 & Valid \\
\cline { 2 - 5 } & 20 & 0,588 & 0,2658 & Valid \\
\hline
\end{tabular}

Berdasarkan data tersebut diketahui bahwa semua item soal yang berjumlah 20 soal tergolong valid. hal ini disebabkan hasil $r_{\text {hitung }}$ semuanya lebih besar dari pada $r_{\text {tabel. }}$

2. Uji reliabilitas

Tahap berikutnya setelah uji validitas adalah melakukan uji reabilitas pada instrumen. Uji reabilitas berguna untuk mengetahui konsistensi atau tidaknya suatu instrumen. Untuk mencari besaran angka reliabilitas dapat diketahui dari nilai koefisien Cronbach's Alpha. (Agung Edy Wibowo, 2012) Adapun untuk tingkat reliabilitas instrumen menurut Suharsimi Arikunto adalah sebagai berikut: apabila diperoleh hasil 0,800 sampai pada 1,000 dikategorikan sangat tinggi, apabila diperoleh hasil 0,600 sampai pada 0,799 dikategorikan tinggi, apabila dperoleh hasil 0,400 sampai pada 0,599 dikategorikan cukup, apabila diperoleh hasil 0,200 sampai pada 0,399 dikategorikan 
rendah, dan apabila diperoleh hasil 0,000 sampai pada 0,199 dikategorikan sangat rendah. 13

Berikut adalah tabel hasil uji reabilitas angket pengaruh kepemimpinan guru dan keterampilan manajemen kelas terhadap perilaku siswa di SD Islam 01 YMI Wonopringgo.

Tabel 4. Hasil Uji Reliabilitas Instrumen (X1) Kepemimpinan Guru

\begin{tabular}{|c|c|}
\hline \multicolumn{2}{|c|}{ Reliability Statistics } \\
\hline $\begin{array}{c}\text { Cronbach's } \\
\text { Alpha }\end{array}$ & N of Items \\
\hline .729 & 21 \\
\hline
\end{tabular}

Meninjau data diatas, dilihat bahwa perolehan koefisien alpha sebesar 0,729. Karena angka 0,729 berada pada tingkat 0,600 sampai dengan 0,799, maka dapat diketahui bahwa butir soal tersebut mempunyai kriteria reabilitas yang tinggi.

Tabel 5. Hasil Uji Reliabilitas Instrumen (X2) Keterampilan Manajemen Kelas

\begin{tabular}{|r|r|}
\hline \multicolumn{2}{|c|}{ Reliability Statistics } \\
\hline $\begin{array}{c}\text { Cronbach's } \\
\text { Alpha }\end{array}$ & N of Items \\
\hline .699 & 21 \\
\hline
\end{tabular}

Ditinjau dari data pada tabel 5 diatas, dapat diketahui bahwa nilai koefisien alpha sebesar 0,699. Karena angka 0,699 berada pada tingkat 0,600 sampai dengan 0,799, maka dapat dikatakan bahwa butir soal tersebut mempunyai kriteria reabilitas yang tinggi.

Tabel 6. Hasil Uji Reliabilitas Instrumen (Y) Perilaku Belajar

\begin{tabular}{|r|r|}
\hline \multicolumn{2}{|c|}{ Reliability Statistics } \\
\hline $\begin{array}{c}\text { Cronbach's } \\
\text { Alpha }\end{array}$ & N of Items \\
\hline .720 & 21 \\
\hline
\end{tabular}

Ditinjau dari data pada tabel 6 diatas, dapat diketahui bahwa nilai koefisien alpha sebesar 0,720 . Karena angka 0,720 berada pada tingkat 0,600 sampai dengan 0,799, maka dapat dikatakan bahwa butir soal tersebut mempunyai kriteria reabilitas yang tinggi. hlm. 213

${ }^{13}$ Suharsimi Arikunto, Prosedur Pendidikan Suatu Penedekatan Praktik, (Jakarta: Rineka Cipta, 2010), 
Setelah intrumen di uji validitas dan reliabilitasnya, tahap berikutnya adalah melakukan analisis data, dimana pada tahap analisis data terbagi menjadi dua bagian yaitu uji pra syarat hipotesis dan uji hipotesis. Untuk tahap uji pra syarat hipotesis sendiri dilakukan dengan menentukan hasil dari uji normalitas dan uji linieritas. Lebih lanjut, untuk uji prasayarat hipotesis ditunjukkan melalui penjelasan berikut:

1. Uji normalitas

Pada penelitian ini, penulis menakai analisis Kolmogorov-Smirnov berbantukan aplikasi SPSS untuk menuji normalitas data variabel. sebuah data disebut normal apabila mempunyai Pvalue > 0,05. Adapun hasil uji normalitas tersebut yaitu:

Tabel 7. Hasil Uji Normalitas dengan SPSS

\begin{tabular}{|l|l|r|}
\hline \multicolumn{2}{|c|}{ One-Sample Kolmogorov-Smirnov Test } \\
\hline \multicolumn{2}{|l|}{ N } & \multicolumn{1}{|c|}{ Unstandardized Residual } \\
\hline \multirow{2}{*}{ Normal Parameters ${ }^{\mathrm{a}}$} & Mean & .0000000 \\
\cline { 2 - 3 } & Std. Deviation & 8.21354476 \\
\hline $\begin{array}{l}\text { Most Extreme } \\
\text { Differences }\end{array}$ & Absolute & .197 \\
\cline { 2 - 3 } & Positive & .125 \\
\cline { 2 - 3 } & Negative & -.197 \\
\hline Kolmogorov-Smirnov Z & 1.462 \\
\hline Asymp. Sig. (2-tailed) & .028 \\
\hline a. Test distribution is Normal. & \\
\hline
\end{tabular}

Dari data pada tabel 8 , diperoleh nilai signifikansi data pola hidup sehat dan gerakan masyarakat hidup sehat dalam analisis Komogorov-Smirnov adalah 1,462, sehingga sig $=1,462>0,05$. Jadi, dapat diketahui bahwa data pengaruh kepemimpinan guru dan keterampilan manajemen kales berdistribusi normal.

2. Uji linieritas

Tujuan dari adanya uji linearitas ini guna mengetahui kesesuaian taraf spesifikasi sebuah model. Kaidah yang dipakai untuk menentukan linier atau tidaknya suatu data adalah apabila nilai probabilitas > 0,05 maka sebarannya adalah linier. Adapun perolehan dari uji linieritas dapat diketahui pada tabel 8 dibawah: 
Tabel 8. Hasil Uji Linieritas Data dengan SPSS

\begin{tabular}{|c|c|c|c|c|c|c|c|}
\hline \multicolumn{8}{|c|}{ ANOVA Table } \\
\hline & & & $\begin{array}{c}\text { Sum of } \\
\text { Squares }\end{array}$ & $\mathrm{df}$ & $\begin{array}{l}\text { Mean } \\
\text { Square }\end{array}$ & $\mathrm{F}$ & Sig. \\
\hline \multirow{5}{*}{$\begin{array}{l}\text { Perilaku } \\
\text { belajar * } \\
\text { kepemimpinan } \\
\text { guru }\end{array}$} & \multirow{3}{*}{$\begin{array}{l}\text { Between } \\
\text { Groups }\end{array}$} & (Combined) & 1443.805 & 23 & 62.774 & 3.111 & .002 \\
\hline & & Linearity & 760.667 & 1 & 760.667 & 37.696 & .000 \\
\hline & & $\begin{array}{l}\text { Deviation } \\
\text { from } \\
\text { Linearity }\end{array}$ & 683.138 & 22 & 31.052 & 1.539 & .133 \\
\hline & \multicolumn{2}{|c|}{ Within Groups } & 625.540 & 31 & 20.179 & & \\
\hline & \multicolumn{2}{|l|}{ Total } & 2069.345 & 54 & & & \\
\hline
\end{tabular}

Ditinjau dari data diatas, dikatehui bahwa nilai signifikansi sebesar 0,113 . Sehingga sig 0,113>0,05. Maka bisa diketahui adanya sebuah hubungan linier antara variabel X1 (kepemimpinan guru) dan X2 (keterampilan manajemen kelas) dengan variabel Y (perilaku belajar).

Kemudian lanjut setelah instrumen tes di uji normalitas dan linieritasnya, tahap selanjutnya yaitu tahap pengujian hipotesis. Pada tahap ini gunakan sebagai penentu apakan hipotesis yang ditentukan oleh penulis benar-benar terbukti atau amalah sebaliknya. Jika hasil dari penelitian menunjukkan hipotesis yang diajukan oleh penulis di tolak maka perlu diadakan tinjak lanjut secara lebih. Adapun langkah-langkah yang dilakukan dalam tahap pengujian hipotesis meliputi:

1. Menentukan hipotesis

Penelitian ini memiliki hipotesis sebagai berikut:

$\mathrm{H}_{1}=$ Terdapat pengaruh kepemimpinan guru (X1) terhadap perilaku belajar siswa (Y).

$\mathrm{H}_{2}=$ Terdapat pengaruh keterampilan manajmen kelas (X2) terhadap perilaku belajar siswa $(\mathrm{Y})$.

$\mathrm{H}_{3}=$ Terdapat Pengaruh kepemimpinan guru (X1) dan keterampilan manajemen kelas (X2) secara simultan terhadap perilaku belajar siswa (Y).

Adapun untuk hipotesis yang diajaukan oleh penulis yaitu terdapat pengaruh kepemimpinan guru dan keterampilan manajemen kelas terhadap perilaku belajar siswa.

2. Pengujian hipotesis $\mathrm{H}_{1}$ dan $\mathrm{H}_{2}$ dengan Uji $\mathrm{t}$

Untuk hasil pengujian hipotesis $\mathrm{H} 1 \mathrm{dna} \mathrm{H} 2$ dapat dilihat pada tabel 9 berikut: 
Tabel 9. Hasil Persamaan Regresi Linier Berganda

\begin{tabular}{|c|c|c|c|c|c|c|}
\hline \multicolumn{7}{|c|}{ Coefficients $^{\mathrm{a}}$} \\
\hline & & \multicolumn{2}{|c|}{$\begin{array}{l}\text { Unstandardized } \\
\text { Coefficients }\end{array}$} & \multirow{2}{*}{$\begin{array}{c}\text { Standardized } \\
\text { Coefficients }\end{array}$} & \multirow[b]{2}{*}{$\mathrm{t}$} & \multirow[b]{2}{*}{ Sig. } \\
\hline \multicolumn{2}{|c|}{ Model } & $\mathrm{B}$ & Std. Error & & & \\
\hline \multirow[t]{3}{*}{1} & (Constant) & -5.580 & 8.110 & & -.688 & .494 \\
\hline & Kepemimpinan Guru & .544 & .098 & .525 & 5.562 & .000 \\
\hline & Manajemen kelas & .518 & .112 & .437 & 4.632 & .000 \\
\hline
\end{tabular}

Berdasarkan tabel diatas pada pengujian hipotesis 1 (H1) diketahui nilai Sig. Untuk pengaruh X1 terhadap Y sebesar 0,000 $<0,05$ dan nilai t hitung 5,562 $>\mathrm{t}_{\text {tabel }}$ 1,674, karena niali signifikansi lebih besar daro 0,05 dan thitung juga lebih besar dari t tabel maka dapat dikatakan bahwa $\mathrm{H} 1$ diterima yang berarti terdapat pengaruh X1 terhadap Y. Kemudian untuk hipotesis kedua $(\mathrm{H} 2)$ diketahui nilai Sig. Untuk X2 terhadap Y adalah sebesar $0,000<0,05$ dan nilai t hitung 4,632 > t tabel 1,674 karena nilai signifikansi lebih besar dari 0,05 dan t hitung juga lebih besar dari t tabel maka dapat dikatakan bahwa $\mathrm{H} 2$ diterima yang berarti terdapat pengaruh X2 terhadap Y. Sehingga dari hasil tersebut dapat disimpulkan bahwa $\mathrm{H} 1$ dan $\mathrm{H} 2$ sama-sama diterima dan menunjukan adanya pengaruh . Lebih lanjut dari data diatas juga dapat dilihat Koefisien korelasi bernilai positif, artinya terjadi pengaruh positif kepemimpinan guru terhadap perilaku siswa dan juga keterampilan manajemen kelas terhadap perilaku siswa.

3. Pengujian hipotesis $\mathrm{H} 3$ dengan uji $\mathrm{F}$

Berikut adalah hasil uji hipotesis tang akan dijadikan penentu pengaruh dari $\mathrm{H} 3$ menggunakan Uji F: 
Tabel 10. Hasil Uji Hipotesis

\begin{tabular}{|ll|c|c|c|c|c|}
\hline \multicolumn{7}{|c|}{ ANOVA $^{\mathrm{b}}$} \\
\cline { 2 - 6 } & Model & Sum of Squares & Df & $\begin{array}{c}\text { Mean } \\
\text { Square }\end{array}$ & F & Sig. \\
\hline 1 Regression & 1142.899 & 2 & 571.450 & 32.075 & $.000^{\mathrm{a}}$ \\
& Residual & 926.446 & 52 & 17.816 & & \\
& Total & 2069.345 & 54 & & & \\
\hline
\end{tabular}

a. Predictors: (Constant), Manajemen kelas, Kepemimpinan Guru

b. Dependent Variable: Perilaku belajar

Berdasarkan output tabel 2 diatas, diketahui nilai signifikansi untuk pengaruh X1 dan X2 secara simultan terhadap Y adalah sebesar 0,000 < 0,05 dan nilai F hitung 32,075 $>\mathrm{F}$ tabel 4,02. Sehingga dapat disimpulkan bahwa H3 diterima yang berarti terdapat pengaruh X1 dan X2 secara simultan terhadap Y. Adapun untuk mencari F tabel dapat dilakukan dengan cara mencari $\mathrm{df}=\mathrm{N}-2=55-2=53$, maka untuk melihat $\mathrm{F}$ tabel dapat diketahui pada nilai responden 53 .

4. Uji Determinasi (R Square)

Koefisien determinasi ( $\mathrm{R}$ Square) berguna sebagai penentu seberapa besar variabel bebas (program gerakan masyarakat sehat) dapat menjelaskan variabel terikat (pola hidup bersih dan sehat). Berikut ini adalah hasil uji determinasi (R Square).

Tabel 11. Hasil Uji Determinasi

\begin{tabular}{|l|r|r|r|r|}
\hline \multicolumn{5}{|c|}{ Model Summary } \\
\hline Model & \multicolumn{1}{|c|}{$\mathrm{R}$} & R Square & $\begin{array}{c}\text { Adjusted R } \\
\text { Square }\end{array}$ & $\begin{array}{l}\text { Std. Error of } \\
\text { the Estimate }\end{array}$ \\
\hline 1 & $.743^{\mathrm{a}}$ & .552 & \multicolumn{3}{|c|}{.535} & 4.221 \\
\hline
\end{tabular}

Berdasarkan output diatas diketahui R Square sebesar 0,552 hal ini mengandung arti bahwa pengaruh variabel $\mathrm{X} 1$ dan $\mathrm{X} 2$ secara simultan terhadap variabel $\mathrm{Y}$ adalah sebesar $55,2 \%$. 


\section{KESIMPULAN}

Berdasarkan dari hasil uji regresi linier berganda yang dilakukan oleh peneliti menjelaskan bahwa kepemimpinan guru dan keterampilan manajemen kelas mempunyai pengaruh terdapat perilaku siswa. hal ini dibuktikan dengan perolehan nilai $\mathrm{F}$ hitung 32,075 $>\mathrm{F}$ tabel 4,02. Sehingga dapat disimpulkan bahwa terdapat pengaruh kepemimpinan guru dan keterampilan manejemen kelas terhadap perilaku belajar sidswa di SD Islam 01 YMI Wonopringgo.

Berdasarkan uji regresi linear berganda, didapatkan koefisien determinasi (R Square) sebesar 0,552 yang berarti pengaruh variabel bebas terhadap variabel terikat adalah 55,2 \% . Sehingga dapat ditarik kesimpulan bahwa pengaruh kepemimpinan guru dan keterampilan manajemen kelas di SDI 01 YMI Wonopringgo yaitu sebesar 55,2 \% dan selebihnya dipengaruhi oleh faktor yang lain.

\section{DAFTAR PUSTAKA}

Ardy, N. W. (2013). Manajemen Kelas: Teori dan Aplikasi untuk Menciptakan Kelas yang Kondusif. Yogyakarta: Ar-Ruzz.

Arikunto, S. (2006). Prosedur Penelitian Suatu Pendekatan Praktis. Jakarta: Rineka Cipta. Arikunto, S. (2010). Prosedur Pendidikan Suatu Penedekatan Praktik. Jakarta: Rineka Cipta. Hasan, M. I. (2002). Pokok-Pokok Materi Metode Penelitian dan Aplikasinya. Jakarta: Ghalia Indonesia.

Kartini, K. (1992). Pemimpin dan Kepemimpinan. Jakarta: PT Grafindo.

Mahmudah, U. (2020). Metode Statistika: Step by Step. Pekalongan: Penerbit NEM.

Salafudin \& Nalim. (2012). Statistik Deskripstif. Pekalongan: STAIN Pekalongan Press.

Salim, P. (1991). Kamus Besar Bahasa Indonesia Kontemporer. Jakarta: Modern English Press.

Siahaan, A. (2018). Kepemimpinan Pendidikan. Medan: CV. Widya Puspita.

Suryana, E. (2019). Administrasi Pendidikan dalam Pembelajaran. Yogyakarta: Deepublish.

Syah, M. (2010). Psikologi Pendidikan dengan Pendekatan Baru. Bandung: Remaja Rosdakarya.

Untung, S. (2019). Metode Penelitian Teori dan Praktik Riset Pendidikan dan Sosial. Yogyakarta: Litera.

Widasworo, E. (2018). Cerdas Pengelolaan Kelas. Yogyakarta: DIVA Press. 